\section{Commentary: Preoperative tobacco burden - a risk factor, but not a roadblock for safe resection}

\author{
Matthew A. Steliga, MD
}

The article by Al Natour and colleagues ${ }^{1}$ shares valuable perspectives on the interplay between tobacco use and perioperative risk for lung resection. As tobacco use is the leading risk factor for developing lung cancer, and as nicotine is incredibly addictive, it is not surprising that some surgical patients are smoking and unable to quit. Physicians and patients may have a sense of futility-the patient has cancer, and they may consider it "too late." In fact, the authors found no significant difference in mortality or complications between those who had quit and those who had not. So does it make a difference? Outcomes of this cohort are quite good overall; increasing use of minimally invasive surgery, appropriate patient selection, and quality-driven perioperative care pathways may mitigate risk so that patients benefit from surgery without appreciable risk increase. The risk may be there, but diminished in high-performing systems with excellent outcomes overall.

Some may consider quitting preoperatively not beneficial and not worth the hassle. However, regardless of whether we see changes in perioperative outcomes related to tobacco, patients' goals do not end at 30 days. Their horizon for success includes a 5-year survival benchmark, and our priorities should align with that. For those needing adjuvant therapy, smoking impacts the efficacy and toxicity of chemotherapy and/or radiotherapy. ${ }^{2}$ In earlystage disease, cessation may confer benefits in terms of the risk of other primary tumors, cardiovascular disease, and respiratory illnesses. The National Lung Screening Trial (NLST) evaluated benefits of screening for lung cancer, but we can also learn about the impact of tobacco on

From the Division of Thoracic Surgery, University of Arkansas, Little Rock, Ark. Disclosures: The author reported no conflicts of interest.

The Journal policy requires editors and reviewers to disclose conflicts of interest and to decline handling or reviewing manuscripts for which they may have a conflict of interest. The editors and reviewers of this article have no conflicts of interest.

Received for publication Nov 23, 2020; revisions received Nov 23, 2020; accepted for publication Nov 23, 2020; available ahead of print Dec 3, 2020.

Address for reprints: Matthew A. Steliga, MD, Division of Thoracic Surgery, Department of Surgery, University of Arkansas for Medical Sciences, 4301 W Markham St \#725, Little Rock, AR 72205 (E-mail: MASteliga@uams.edu).

J Thorac Cardiovasc Surg 2021;162:1386-7

$0022-5223 / \$ 36.00$

Copyright (c) 2020 by The American Association for Thoracic Surgery

https://doi.org/10.1016/j.jtcvs.2020.11.134

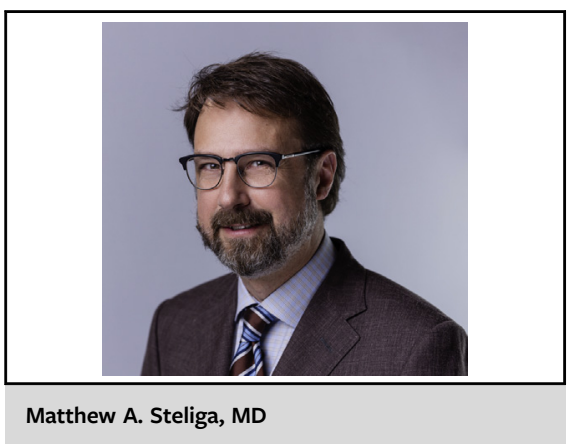

CENTRAL MESSAGE

This statewide collaborative study demonstrates that current smoking status does not impact short-term outcomes on lung cancer resection, and surgery can be done without increased risk in these patients.

this population as well. Throughout the NLST, 24.1\% (930 of 3856) died of lung cancer; interestingly, $24.8 \%$ died of cardiovascular disease, $22.3 \%$ died of other neoplasms, and $10.4 \%$ died of respiratory illness. ${ }^{3}$ As many survivors of lung cancer surgery die of tobacco-related illnesses, our goal to improve survival needs to target deaths from all causes. A surgical intervention may be the key turning point for patients to quit, providing years of future benefit.

Another praiseworthy aspect of this article is the collaboration between the Michigan Society of Thoracic and Cardiovascular Surgery and Blue Cross and Blue Shield to delve into quality improvement with aligned goals. This collaboration between surgeons in academic and nonacademic hospitals with the insurance industry not only reflects actual practice in the community, but also sets a great example for how further work with aligned goals of all parties will ultimately benefit our patients. Finally, as we read this report and reflect on data demonstrating that continued smoking is not associated with poorer shortterm outcomes, this calls into question the rationale for limiting surgery in those unable to quit. As surgical resection is the standard of care for early-stage lung cancer, ${ }^{4}$ and resection can safely be done in those who smoke, ${ }^{1}$ we should continue to encourage cessation to reap long-term benefits; and surgical resection can still offer long-term 
cure and be accomplished with acceptable risk to those patients unable to quit.

\section{References}

1. Al Natour RH, He C, Clark MJ, Welsh R, Chang AC, Adams KN. The impact of tobacco load versus smoking status on outcomes following lobectomy for lung cancer in a statewide quality collaborative. J Thorac Cardiovasc Surg. 2021;162: 1375-85.e1.
2. Warren GW, Sobus S, Gritz ER. The biological and clinical effects of smoking by patients with cancer and strategies to implement evidence-based tobacco cessation support. Lancet Oncol. 2014; 15:e568-80.

3. National Lung Screening Trial Research Team, Aberle DR, Adams AM Berg CD, Black WC, Clapp JD, et al. Reduced lung-cancer mortality with low-dose computed tomographic screening. N Engl J Med. 2011;365: 395-409.

4. National Comprehensive Cancer Network. NCCN Clinical practice guidelines in non-small cell lung cancer. Version 8.2020. Available at: https://www.ncen.org/ professionals/physician_gls/pdf/nscl_blocks.pdf. Accessed December 1, 2020.
See Article page 1375.

\section{Commentary: Do we need to search for a patient's cigarettes or just count his or her wrinkles when counseling for lung cancer resection?}

\author{
Dirk Van Raemdonck, MD, PhD, ${ }^{\mathrm{a}, \mathrm{c}}$ \\ Herbert Decaluwe, MD, PhD, ${ }^{\mathrm{a}, \mathrm{c}}$ \\ Paul De Leyn, MD, PhD, ${ }^{a, c}$ and \\ Kristiaan Nackaerts, $\mathrm{MD}, \mathrm{PhD}^{\mathrm{b}, \mathrm{c}}$
}

Smoking increases your risk of problems during and after your operation. Quit smoking 4-6 weeks before your operation. That is a morsel of strong advice among many provided in the surgical patient education program published by the American College of Surgeons to prepare for the best recovery after surgery. ${ }^{1}$

Smoking cessation remains an important facet of the management of patients with lung cancer requiring pulmonary resection. However, the influence of short-term

\footnotetext{
From the Departments of ${ }^{\mathrm{a}}$ Thoracic Surgery and ${ }^{\mathrm{b}}$ Pneumology, University Hospitals Leuven, Leuven, Belgium; and ${ }^{\mathrm{c}}$ Department of Chronic Diseases and Metabolism, Katholieke Universiteit Leuven, Leuven, Belgium.

Disclosures: The authors reported no conflicts of interest.

The Journal policy requires editors and reviewers to disclose conflicts of interest and to decline handling or reviewing manuscripts for which they may have a conflict of interest. The editors and reviewers of this article have no conflicts of interest.

Received for publication Dec 8, 2020; revisions received Dec 8, 2020; accepted for publication Dec 8, 2020; available ahead of print Dec 25, 2020.

Address for reprints: Dirk Van Raemdonck, MD, PhD, Department of Thoracic Surgery, University Hospital Gasthuisberg, Herestraat 49, B-3000 Leuven, Belgium (E-mail: dirk.vanraemdonck@uzleuven.be).

J Thorac Cardiovasc Surg 2021;162:1387-8

$0022-5223 / \$ 36.00$

Copyright (c) 2020 by The American Association for Thoracic Surgery

https://doi.org/10.1016/j.jtcvs.2020.12.050
}

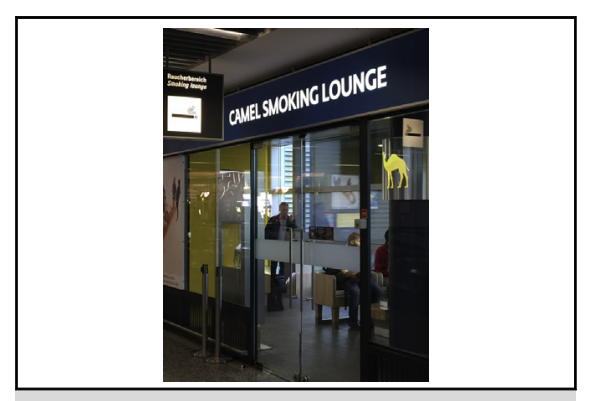

Smoking lounge: Last stop for a cigarette on the way to have my lung cancer resected?

\section{CENTRAL MESSAGE \\ Never too late to quit. Smoking cessation remains important in the management of lung cancer patients requiring pulmonary resection, but discussion on best timing continues.}

smoking cessation on surgical outcome remains unclear. To shed some light on this, authors from a quality collaborative in the State of Michigan report the results of a voluntary statewide review. In a cohort of 2267 patients undergoing lobectomy for lung cancer at 14 Michigan hospitals, postoperative 30 -day mortality was $1.5 \%$, and major morbidity was $9.6 \%$. Smoking status at the time of surgery was not associated with poor outcome $(P=.56)$, although tobacco load in pack-years $(P=.03)$ was a significant independent predictor of mortality and morbidity along with male sex $(P=.04)$, body mass index $(P<.001)$, Zubrod score $(P=.02)$, and open thoracotomy approach $(P<.001)$. Higher American Society of Anesthesiologists class and advanced tumor stage were marginally associated with worse combined outcome $(P=.06)$. Generated plots 